\title{
TOWARDS IDENTIFICATION OF NEW TOURISM \\ INDUSTRY OCCUPATIONS FOR CURRICULA DEVELOPMENT OF EGYPTIAN TOURISM AND HOSPITALITY HIGHER EDUCATION
}

\author{
SABREen G. Abd El-JaliL \\ Faculty Of TOURISM AND Hotels, SOUth Valley UNIVERSity, LUXoR \\ BRANCH, EGYPT \\ Nahla Mohamed Helmy \\ High Institute of Tourism, Hotels and Restoration, Abu QIR, \\ ALEXANDRIA, EGYPT \\ Khaled Soliman Abd Elhalem \\ Faculty Of TOURISM AND HOTELS, SOUth Valley UNIVERSITY, LUXoR \\ BRANCH, EGYPT
}

\begin{abstract}
Recently, curricula development is one of the most significant aspects in education reform with special focus on its link with the labor market. The research is addressing this link pertaining to the newly emerged occupations that are considered new trends in the international tourism field and regarded as new potentials in the Egyptian tourism labour market that also needed by employers. This research is aiming at identifying these top priorities new occupations and prepare a formulated diagram for linking them with curricula development in tourism and hotels colleges and high institutes. A pilot study has been done with selected academics and tourism market experts to identify the Egyptian labour market needs for new occupations. The field survey has utilized an interview with 13 authorized persons working in governmental and authorized associations related to tourism industry, as well as a questionnaire with 50 trade people working in the Egyptian tourism market within four tourist destinations: Cairo, Sharm El Sheikh, Luxor, Aswan and Hurghada. The main objectives of interview and questionnaire are to stress on the Egyptian labour market needs acknowledged by the pilot study and consequently identify the new occupations. Field survey's results concluded that there are seven new occupations represent the urgent needs of the labor market in both inbound
\end{abstract}


services and hotel management sub-sectors. Analysis of both interview and questionnaire has been employed as guidelines for structuring a suggested diagram linking new occupations with curricula development. Finally, it recommended that this proposed diagram is submitted to one of the curricula development and/or education reform authorized organizations for adoption, development and deployment.

KEYWORDS: Curricula Development, Higher Education, Labour Market, New Occupation.

\section{INTRODUCTION}

We are living now in the world of globalization where tourism exceeds geographical space, time, cultures and values (Liburd, et al, 2018). The important changes that have been emerged in the competitive environment of business are social cultural changes, technological progresses, increasing interest in sustainability as well as the friendly environment practices (Km and Sharma, 2011). Such changes and trends played a key role in developing universities' curricula so as to meet the needs and job opportunities' requirements created by the tourism sector's labor market (Liburd, et al, 2018).

Consequently, tourism and hospitality industry, which is the core business of globalization, should take in mind the strong impact of global context related to such new changes and trends. Certainly, globalization will affect all sides of tourism and hospitality industry that should move across worldwide boundaries, such as guest relation management, employees, product and service, and investment resources. Accordingly, globalization aspects in the future will be the competitive edge among all tourism and hospitality entities (Zhao and Jing, 2009).

The past century witnessed great changes especially in those pertaining to recent trends in the demand and supply of worldwide health tourism (Csirmaz and Peto, 2015). These changes resulted from the pressure ad need to improve the life quality which consequently resulted in the urgent need for wellness and spa hotels. The commercial philosophy of wellness and spa hotels involve face and body care, health improvement through various wellness and spa methods, mental training and wellness regime. Some countries with 
potential tourism development, are improving their management of spa and wellness tourism. On the other hand, other tourist destinations are progressively regarded as wellness and spa tourist site (Batinic, 2013).

According to Zhao and Jing (2009), remarkable changes emerged in tourism and hospitality sector which resulted in many challenges for altering the overall educational processes involving curricula, academic material and instructional performance.

New occupations are evolving now in the tourism sector with new skills and job requirements to meet the needs of the new trends (Stanciulescu and Bulin, 2012). Meeting tourism labor market needs and prospects is still the main goal behind tourism and hospitality curricula development (Luka and Donina, 2014 ). Academics need to be continuously knowledgeable with such new trends in the market since they urgently need a stronger relation between education and labor market, so as to be on the right track of coping with the new job requirements needed in the market (Stanciulescu and Bulin, 2012).

The main target of every curricula developer and planner is to tailor curricula for the graduates that meet required competencies in the labour market and enabling them to come up with the tourism environment changes in tourism and hospitality business (Luka and Donina, 2014).

The main purpose of this paper is to identify the new occupations recently raised in the Egyptian Tourism market that come up with the new worldwide trends in the industry so as to link them with developing the curricula of the Egyptian tourism and hotel management higher education. The study has first utilized a pilot study with tourism experts to firstly stress on new international tourism trends and market needs. The field survey study depends on mixed approaches methodology, which is popular in business researches (Veal,2006): the first is quantitative methodology represented in questionnaire targeted 50 trade people working in the Egyptian tourism market whereas, the second is qualitative methodology reflected in an interview conducted with 13 persons working in 9 governmental authorized associations related to tourism sector.

\section{LITERATURE REVIEW}

Hospitality industry is changing over time with new development and design (Akhalaia and Vasadze, 2016; Ju and Lo, 2014). Changes also 
involve customers' needs, demands and desire e.g. the increased need for security, health preservation, focus on ecology, dietary and healthy food, pure nature of accommodation, plus the increasing demand for adventure and excitement. Changes also include convention facilities and incentive offerings, paying visits to cities, massive sports; this is in addition to cultural and religious visits, business events and new travel motivation (Batinic, 2013). Current tourism and hospitality trends also include: IMCE tourism (Meetings, Incentives, Conferences and Exhibitions). According to UNWTO definitions, MICE type of tourism is serving the meeting industry too, when the main purpose of the tourism visit is either business or professional. This means that the visit is more related to attending meetings, conferences or congresses, trade fairs and exhibitions, and additional business and professional aims (Patino, et al, 2016).

Recently, animation has become one of the competitive advantages of hotel packages, offered to the guest, as entertainment service. Hotels' interests now focus on meeting the modern demands and needs of various guests' segmentation especially the age groups. Animation plays a key role in realizing entertainment, sports and recreation facilities, as it creates a unique character for the guests with their activities (Batinic, 2013).

Nowadays, ecology has become a substantial issue represented by the global interest in environmental change and sustainability which has a strong relation to hospitality, tourism, entertainment and athletics sector. This is replicated by customer preference on such ecological matters such as green elements within different tourism and hotel establishments (Galbraith and Bankhead, 2012). Currently, consumers are socially and environmentally aware of ecology significance in sense of environment protection and its positive impact on money return. To be more specific, ecological factor has become one the measurement criteria for customers' choices among all tourism and hospitality properties, services and facilities (Batinic, 2013). Furthermore, today and future customers expected to be more knowledgeable and acquainted with the undesirable influence of tourism environment, the fact that consequently, let them more responsible with the sustainability issues (Rao and Pradesh, 2014).

\section{TOURISM HIGHER EDUCATION AND LABOR MARKET NEEDS}

Tourism and Hospitality sector is rising so fast with the urgent need for qualified manpower (Bamford, 2012). Biswakarma (2016) mentioned that the World Travel and Tourism Council (WTTC) in 
2016 has proved that the significance of tourism and hospitality mainly depend on labor force within both developed and developing countries. This is due to the fact that it is expected that tourism and hospitality related activities will create 296.2 million jobs, or 9.2 per cent of worldwide jobs by 2018. Consequently, skillful, educated and committed workforces are required to fill such jobs to maintain the quality of services offered in the sector (Bamford, 2012).

In the last decades, the quality of education, with its strong relation to the tourism industry's employment needs, has been regarded as the first priority discussion points. As a result of globalization and the international economic recession, curricula development is now needed to come up with the fast changes in the market. Moreover, there is a rapid request for educating employees who intend to work in the tourism sector to face the unpredictable challenges related to the quick shift in the tourism environment (Luka and Donina, 2012).

Many recent published researches are addressing the issue of tourism industry needs in terms of competencies and skills. Since tourism industry is a broad one, there are wide knowledge and skills needed for the staff working in the sector within different sub-sectors such as hotels, tour operation, and rural tourism enterprise. This is plus knowledge and skills needed from one organization to another, regardless of the organization type: public, private or NGO (Luka and Donina, 2014).

As a result of the rapid changes in the both modern economy and tourism sector environment as well as the high demands for competent staff, there is a wide gap between the academic programs in different educational associations compared to the employment needs in the market (Zaitseva,et al, 2016).

Tourism manpower will have to cope with the increasingly fluctuating needs and requirements of the market. Sometimes new skills and knowledge should be educated with application on the ground to substitute the current methods of implementation. Moreover, employees have to alter their old roles into new ones so as to be enhanced as extra skills and abilities. Furthermore, the size of the job profile will have to change to meet the shift in market needs and requirements (Willimas,et al,2012).

Evaluating the curriculum in the tourism and hospitality sector is implemented through utilizing various approaches and tactics. "Needs assessment" which has been a familiar form of evaluation has been tackled in the tourism and hospitality industry, and is now also 
progressively being used in hospitality and tourism academic associations. Curricula should be strongly related to the industry new trends so as to be pragmatic for hoteliers and tourism specialists (Conradie, 2012).

\section{NEW JOBS AND NEW SKILLS IN TOURISM AND HOSPITALITY INDUSTRY}

New job skills may be demanded during the developing employment market. This clarifies the need to take in consideration the changing skills requirements which hospitality graduates should meet due to the existence of new trends. Therefore, these exposures should push colleges to reform their concentration on the skills required to boos graduate employability (Sadik, 2017).

International labor organizations (2010) stated that: New occupations have been noticed and echo the nature of new products and services offered by the market, the need for green tourism products will last for growing, and increasing demand for wellness and medical tourism. Consequently, these new knowledge and skills have been highlighted. The question here is "will outsourcing be required to renew graduates' skills to new market needs?

In Germany, a research has been conducted for identifying work qualifications in the country of Germany, as one of the outcomes of a national project named "Trend Qualifications" funded by the Federal Ministry of Education and Research of Germany. Analysis has demonstrated that training practices are adjusted to suit the modern job profiles that currently exist in the labour market. Moreover, training practices are tailored to meet the requirements of such new jobs' operational standards. The overall process is developed directly or indirectly depending on different interrelated various changes: technology, business organization, political and economic environment which has been recently influenced by globalization, this is plus the change in the needs of individuals and society. In addition, there are other considerable changes such as internet development, which emerged during the recent years, as well as the enormous changes in new skills' requirements ( Becic and Crnjar, 2009).

It is important to concentrate on the expected and potential visions that might occur in the future so as to identify the occupational skills' requirements of tourism workforce. Many upcoming jobs that might emerge in the future are not occurring now. Therefore, approaches should be prepared to develop knowledge, skills and competencies 
for future prospective jobs. It is proposed that there are new tourism occupations will appear in the future such as Destination concierge specialists, Sustainable tourism consumption auditors, Personal event coordinators, Production, bundling specialists, Transit managers, logisticians, Experience enhancers/customizers, Corporate sharing managers, Augmented reality destination managers (Dredge, 2016). Moreover, there are many skills that will be urgently needed in the future like Events Management Skills, Computer Skills, Negotiation Skills Organizational Ability, Networking Ability (Wang, et al, 2009).

According to the pilot study results, there are seven recent trends in tourism industry stressing on the importance of seven top priority new occupations in tourism and hospitality field in Egypt. These occupations need researching and development to be an actual active instrument for curricula development in tourism and hotels' colleges and High Institute. These occupations are stated as follows: MICE Organizer, Eco-Guide, Religious Guide, Medical Tourism Specialist, Animator, Dietary and Nutritious Food Specialist and Friendly Environment (Green Hotels) Expert. Below is the review of literature extracted from researches, papers and textbooks addressing these seven occupations and visualize the real significance of such occupations that support a great deal in the study development. It is proposed that new tourism occupations will appear in the future such as Destination Concierge Specialists, sustainable tourism consumptions auditors, personal event coordinators, production bundling specialists, transit managers, logisticians,

Abu ElAzm and Abd Eljalil (2017) confirmed that event organizers regard very significant issues in the work such as staff, host community, venue and logistics, sponsorship, media, participants, vendors, and sustainability. The trend of travelling abroad for medical purposes and cure has been broadly developed during the last 10 years and proposed to continue also in the coming decade. This trend is called "Medical Tourism. Accordingly, there is a new occupation has been emerged, which is named "Medical Tourism Facilitator", who is responsible for organizing the whole trip of medical tourism. Certainly, with the existence of such job, medical tourism in different destinations will be developed. The work activities of this occupation can be executed with the country of the medical tourists and/or in the medical tourism destination (Cormany and Baloglu, 2010). 
As stated by Jakovlev,et al,(2014) Animator is one of the tourism workers, who possesses general features and should match the animation pre-requisites and roles. His role starts with the first contact with visitors, and continues contacting with guests during their stay i.e. his work activities starts from guest arrival till departure. This contact includes meeting with guests, advertising for animation activities, in sense of meeting all their interests, demands and preferences. Animators are required to have specific characteristics and physical fitness. Hence, they have to perform special customer-focused tasks for inspiring tourists during their accommodation.

According to Millar and Baloglu (2008) Green Hotels also named eco-friendly hotels, ecologically friendly hotels or environmentally friendly hotels. Managers of Green Hotels are implementing programs for saving water, energy and minimize hard waste as well as saving money so as to share in protecting the global environment.

Steinsdottir (2014) mentioned that tour guides and their activities play a very significant role in the future of religious tourism. Tour guide works as an instructor and information provider. His role represents the strong link between travelers and the local community and need to share information within the religious location. Religious tourism is based on professional and reliable tour guides. It is expected that this type of tourism will rise in the future with positive impact on world's globalization (Steinsdottir, 2014).

Skanavis and Giannoulis (2010) stated that eco-tour guide is someone who performs his activities with payment or on a voluntary basis. However, in all cases, whether paid or not paid, his work is depending on the natural, cultural and ecotourism principles together with interpretation. In addition to his/her roles, guides' educational role has to be highly considered as the most important one. The ecoguide can play a very active role in the eco-tourist visit through protecting the natural and cultural environment by acting as interpreter of the environment, environmental preserver and supporter, information specialist and values conservationist.

Otterbacken and Harrington (2009) stated that nowadays guests are so much aware about what they eat and became so sensible towards their health. They are assuming a wider potential wellness programs favor their living. Furthermore, customers are now more cautious about allergy, and food contents. They are also refusing products that contain harmful ingredients. According to Melia (2011) most of 
guests are now planning for their diets by preventing themselves from eating some fatty food and avoiding some items that may cause allergy. This is in addition to those that go on diet for losing weight and choosing less fatty food with minimum calories. This reflects the significance and necessity of recruiting dietary and nutritious food specialist that implement dietary programs in hotel and tourist establishments.

\section{DEVELOPMENT OF THE TOURISM HIGHER EDUCATION}

The tourism higher education reform is indispensable to support in graduating high caliber suitable for confronting the quick and growing change in the tourism industry in both quantity and quality (Wang, et al, 2009). Higher education institutions attempt to be in constant contact with the tourism market to come up with all changes and progression that happen in the market. The UN World Tourism Organization Ted Qual Program is aiming at improving the quality of tourism education, training and research agenda. The program has provided evaluation criteria for tourism curricula. The degrees of incorporation of stakeholders needs are considered as a major component of the evaluation criteria (Luka and Donina, 2012).

Tourism Sector and education should work in collaboration to maintain the professionalization of tourism and reach the quality assurance of the education for a tourism career which is relevant to employers' needs. This leads to the market based tourism curriculum, which is effective for all parties as it would be tailored to tourism market needs rather than tourism educators' decision (Wang, et al, 2009).

The role of stakeholders in curriculum planning and development could be regarded in two main aspects: to affect the construction of curricula and to evaluate, which directly contributes to the curriculum development. Stakeholders are involved in the core areas and courses/modules that have to be included in the curriculum (Luka and Donina, 2012).

Curricula developers should comprehend the skills and competencies needed by employers in the tourism sector so as to assure the quality of training they provide and graduate the best candidates to fill their job vacancies. To develop curricula for tourism education, there are key important features might be taken in consideration such as the following: (1) the fact that curricula objectives are designed to qualify students with the ability to share positively in the job market and perform their tasks and responsibilities professionally. (2) 
Curricula planning should match the labor market needs. (3) To develop tourism higher education curricula, there is a need to be in direct ccontact with other tourism-related industries and make the appropriate use of social resources to review students' knowledge, skills, attitudes and values in schools as well as their performance in the labor market, as soon as students are graduated (Erisher,2013).

\section{METHODOLOGY}

This study is based on descriptive methodology which is popular in business research (Veal, 2006). Moreover, the study depends on mixed approaches methodology: the first is quantitative methodology represented in questionnaire whereas, the second is qualitative methodology reflected in interview.

To identify the most significant new occupations required by the Egyptian tourism market, three instruments of field survey have been utilized as follows:

\section{PILOT STUDY TO IDENTIFY GENERALLY THE NEW OCCUPATIONS}

This pilot study has addressed a number of academic and tourism market experts to identify the common needs in the Egyptian Tourism market for the new occupations. Academic experts are those who participated in curricula development of tourism and hotels higher education and also play an effective role in approving the study plan of tourism and hotels' colleges and institutes. As for the tourism market experts are those that have long experience in the tourism and hospitality market and work in managerial positions in well-known and multinational tourism associations that really come up with the recent trends in the worldwide tourism field. Two academic experts have been consulted and three tourism market experts have been discussed. The pilot study has been done for 3 month starting from October till December 2017. Consequently, the pilot study resulted in classifying the new occupations into two segments: top priority new occupations and less priority new occupations. They identified the top priority new occupations as those that highly needed by the Egyptian market and correspond to the worldwide new trends. They also need development through preparation of occupational profile to serve in curricula development. This occupational profile consists of two important stages: preparation of job description and then setting up the intended learning outcomes (ILOs). Some of the new occupations already exist in the Egyptian market but have not been developed yet and need to be incorporated with the academic programs of tourism and hotels 
higher education colleges and institutes. Therefore, seven new occupations have been specified which are: MICE Organizer, EcoGuide, Religious Guide, Medical Tourism Specialist, Animator, Dietary and Nutritious Food Specialist and Friendly Environment (Green Hotels) Expert. On the other hand, less priority occupations has been introduced as those that represent a need in different tourism and hotel establishments but not urgently required. This is owing to the fact that they are not directly related to tourism and hospitality industry. Thus, they could be identified by other sectors and it is not necessary to be involved in the tourism and hospitality higher education curricula.

An interview has been employed to reach research objectives. It has been directed to persons working in authorized tourism related governmental and non-profitable organizations. They have been selected since they have enough tourism experience and decision making plus they are poisoned in leading and top managerial positions in their associations, the fact that certainly reflects their full awareness about the new trends and occupations in the tourism market. The interview lasted for 3 months from January till March 2018. The total numbers of interviewees are 13 persons working in the following 9 associations:

- Ministry of Tourism

- Egyptian Tourism Federation

- Egyptian Tourism Promotion Board

- Egyptian Hotel Association

- Egyptian Travel Agents and Tourism Association

- The Tour Guides Syndicate

- Faculty of Tourism and Hotel Management, Helwan University

- Ministry of Higher Education

- Egyptian Chamber of Tourist Establishments

The questionnaire has been also tackled. It has been distributed among 50 trade people working in Egyptian tourism establishments including travel agents, hotels, resorts and Nile cruises in Cairo, Luxor, Aswan, Hurghada and Sharm El Sheikh. They mostly work in leading positions such as General Manager, Human Resources Managers, Resident Manager and Duty manager. This is definitely represents the Egyptian tourism market. The questionnaire lasted for four five months starting from January till May, 2018. Table 1 clarifies the visited establishments 
Table 1 Types Visited Tourism Establishments

\begin{tabular}{|c|c|c|}
\hline Type of Establishment & Frequency & \% \\
\hline Hotels and Resorts & 28 & 56 \\
\hline Nile Cruises & 8 & 16 \\
\hline Travel Agents & 14 & 28 \\
\hline Total & 50 & 100 \\
\hline
\end{tabular}

The main purpose of both interview and questionnaire is to serve in reaching research objectives in terms of the following:

- Stressing on and approving the significance of top priority occupations that are urgently needed by the Egyptian tourism market

- Ranking top priority occupations according to their importance and urgency of need

- Identifying less priority occupations in the Egyptian tourism market

- Providing ideas for linking the new occupations with the tourism and hotels higher education institutes' curricula development.

\section{THIRD: SAMPLING}

Research sample has been selected randomly with taking in mind the geographical distribution e.g. the 36 hotel establishments cover all tourist cities in Egypt, as typically demonstrated in table 2.

Table 2 Geographical distribution of investigated hotels

\begin{tabular}{|c|c|c|}
\hline Tourist City & $\begin{array}{c}\text { Frequency of Hotel } \\
\text { Establishments }\end{array}$ & $\boldsymbol{\%}$ \\
\hline Sharm El Sheikh & 9 & 25 \\
\hline Hurghada & 8 & 22.5 \\
\hline Luxor and Aswan & 10 & 27.5 \\
\hline Cairo & 9 & 25 \\
\hline Total & 36 & 100 \\
\hline
\end{tabular}

Furthermore, sampling takes into consideration varieties in types of tourism establishments and classification as conveyed in table 3

Table 3 Classifications of Tourism Establishments

\begin{tabular}{|l|l|l|l|l|l|l|l|}
\hline Establishment & \multicolumn{3}{|c|}{ Hotels/Floating Hotels } & \multicolumn{3}{|c|}{ Travel Agencies } \\
\hline Classification & $* * *$ & $* * * *$ & $* * * * *$ & $* * * * *$ & A & B & C \\
\hline
\end{tabular}




\begin{tabular}{|c|c|c|c|c|c|c|c|}
\hline & & & & Deluxe & & & \\
\hline Freq. & - & 7 & 7 & 22 & 9 & 5 & - \\
\hline Percentage & - & $19.5 \%$ & $19.5 \%$ & $61 \%$ & $64.5 \%$ & $35.5 \%$ & - \\
\hline
\end{tabular}

Statistical ANalysis

The Statistical Package for Social Sciences (SPSS) was used to statistically analyze the data. Mean scores and standard deviations are calculated for variables, Kruskal-Wallis $\mathrm{H}$ Test used to to Compare among questionnaire in Luxor/Aswan, interviews in Luxor/Aswan, Questionnaire in Sharm El Sheikh/ Cairo and Interviews in Sharm El Sheikh/ Cairo and determine if there are statistically significant differences between groups. Additionally, The Mann-Whitney U test analysis was also used to compare between The Tourism Occupations According to its Importance and Needs to the Egyptian Tourism Market.

\section{FiLed SURVEY ANALYSIS}

\section{FIRST: TOP PRIORITY NEW OCCUPATIONS}

Kruskal-Wallis $\mathrm{H}$ Test to Compare Among Questionnaires in Luxor/Aswan/Hurghada, Interviews in Luxor/Aswan/Hurghada, Questionnaires in Sharm El Sheikh /Cairo and Interviews in Sharm El Sheikh/ Cairo in terms of the following top priorities new occupations as they are nominated in the pilot study as highly important new occupations in the tourism field: MICE Organizer, Dietary and Nutritious Food Specialist, Animator (Animation Team Member), Green Hotels Specialist, Medical Tourism Specialist, Eco and Safari Guide and finally Religious Tourism Specialist/Guide. Although some of them already exist such as animator, Mice Organizer and Eco-Guide, there is no interest neither from the tourism authorities nor tourism sector academics and experts for further development and setting up skills standards programs so as to be integrated in the tourism and hotels' higher education curricula. Therefore, they need to be adopted and highlighted. 
Table 4 A summary of the Kruskal-Wallis H test Among Questionnaire in Luxor/Aswan, Interviews in Luxor/Aswan, Questionnaire in Sharm El Sheikh/ Cairo and Interviews in Sharm El Sheikh/ Cairo

\begin{tabular}{|c|c|c|c|c|}
\hline Attributes & District & $\begin{array}{l}\text { Mean } \\
\text { Rank } \\
\text { score }\end{array}$ & $\begin{array}{l}\text { Chi- } \\
\text { Square }\end{array}$ & $\begin{array}{c}\text { Exact } \\
\text { Sig. } \\
{[2 *(1-} \\
\text { tailed } \\
\text { Sig. })]\end{array}$ \\
\hline \multirow{4}{*}{$\begin{array}{c}\text { Dietary and } \\
\text { Nutritious Food } \\
\text { Specialist }\end{array}$} & $\begin{array}{l}\text { Questionnaire in } \\
\text { Luxor/Aswan }\end{array}$ & 179.3 & \multirow{4}{*}{38.82} & \multirow{4}{*}{$.001 *$} \\
\hline & $\begin{array}{l}\text { Interviews in } \\
\text { Luxor/Aswan }\end{array}$ & 124.96 & & \\
\hline & $\begin{array}{l}\text { Questionnaire in Sharm } \\
\text { El Sheikh and Cairo }\end{array}$ & 135.94 & & \\
\hline & $\begin{array}{c}\text { Interviews in Sharm El } \\
\text { Sheikh and Cairo }\end{array}$ & 130.69 & & \\
\hline \multirow{4}{*}{$\begin{array}{c}\text { MICE } \\
\text { Organizer }\end{array}$} & $\begin{array}{l}\text { Questionnaire in } \\
\text { Luxor/Aswan }\end{array}$ & 178.61 & \multirow{4}{*}{36.829} & \multirow{4}{*}{$.000^{*}$} \\
\hline & $\begin{array}{l}\text { Interviews in } \\
\text { Luxor/Aswan }\end{array}$ & 100.4 & & \\
\hline & $\begin{array}{l}\text { Questionnaire in Sharm } \\
\text { El Sheikh and Cairo }\end{array}$ & 133.3 & & \\
\hline & $\begin{array}{c}\text { Interviews in Sharm El } \\
\text { Sheikh and Cairo }\end{array}$ & 137.81 & & \\
\hline \multirow{4}{*}{$\begin{array}{c}\text { Animator } \\
\text { (Animation } \\
\text { Team Member) }\end{array}$} & $\begin{array}{l}\text { Questionnaire in } \\
\text { Luxor/Aswan }\end{array}$ & 173.99 & \multirow{4}{*}{33.503} & \multirow{4}{*}{$.001 *$} \\
\hline & $\begin{array}{l}\text { Interviews in } \\
\text { Luxor/Aswan }\end{array}$ & 135.02 & & \\
\hline & $\begin{array}{l}\text { Questionnaire in Sharm } \\
\text { El Sheikh and Cairo }\end{array}$ & 139.43 & & \\
\hline & $\begin{array}{c}\text { Interviews in Sharm El } \\
\text { Sheikh and Cairo }\end{array}$ & 130.81 & & \\
\hline \multirow{2}{*}{$\begin{array}{l}\text { Green Hotels } \\
\text { Specialist }\end{array}$} & $\begin{array}{l}\text { Questionnaire in } \\
\text { Luxor/Aswan }\end{array}$ & 161.61 & \multirow{2}{*}{23.177} & \multirow{2}{*}{$.002 *$} \\
\hline & $\begin{array}{l}\text { Interviews in } \\
\text { Luxor/Aswan }\end{array}$ & 122.1 & & \\
\hline
\end{tabular}




\begin{tabular}{|c|c|c|c|c|}
\hline \multirow[t]{3}{*}{ Attributes } & District & $\begin{array}{l}\text { Mean } \\
\text { Rank } \\
\text { score }\end{array}$ & $\begin{array}{l}\text { Chi- } \\
\text { Square }\end{array}$ & $\begin{array}{c}\text { Exact } \\
\text { Sig. } \\
{[2 *(1-} \\
\text { tailed } \\
\text { Sig. })]\end{array}$ \\
\hline & $\begin{array}{l}\text { Questionnaire in Sharm } \\
\text { El Sheikh and Cairo }\end{array}$ & 142.7 & & \\
\hline & $\begin{array}{l}\text { Interviews in Sharm El } \\
\text { Sheikh and Cairo }\end{array}$ & 100.12 & & \\
\hline \multicolumn{5}{|c|}{ Table (Continued) } \\
\hline \multirow{4}{*}{$\begin{array}{c}\text { Medical } \\
\text { Tourism } \\
\text { Specialist }\end{array}$} & $\begin{array}{l}\text { Questionnaire in } \\
\text { Luxor/Aswan }\end{array}$ & 130.16 & \multirow{4}{*}{19.928} & \multirow{4}{*}{$.001 *$} \\
\hline & $\begin{array}{l}\text { Interviews in } \\
\text { Luxor/Aswan }\end{array}$ & 134.81 & & \\
\hline & $\begin{array}{l}\text { Questionnaire in Sharm El } \\
\text { Sheikh and Cairo }\end{array}$ & 138.71 & & \\
\hline & $\begin{array}{l}\text { Interviews in Sharm El } \\
\text { Sheikh and Cairo }\end{array}$ & 108.88 & & \\
\hline \multirow{4}{*}{$\begin{array}{l}\text { Eco and Safari } \\
\text { Guide }\end{array}$} & $\begin{array}{l}\text { Questionnaire in } \\
\text { Luxor/Aswan }\end{array}$ & 118.96 & \multirow{4}{*}{12.898} & \multirow{4}{*}{$.002 *$} \\
\hline & $\begin{array}{l}\text { Interviews in } \\
\text { Luxor/Aswan }\end{array}$ & 104.27 & & \\
\hline & $\begin{array}{c}\text { Questionnaire in Sharm El } \\
\text { Sheikh and Cairo }\end{array}$ & 102 & & \\
\hline & $\begin{array}{c}\text { Interviews in Sharm El } \\
\text { Sheikh and Cairo }\end{array}$ & 93.56 & & \\
\hline \multirow{4}{*}{$\begin{array}{c}\text { Religious } \\
\text { Tourism } \\
\text { Specialist/Guide }\end{array}$} & $\begin{array}{l}\text { Questionnaire in } \\
\text { Luxor/Aswan }\end{array}$ & 102.8 & \multirow{4}{*}{9.424} & \multirow{4}{*}{$.003^{*}$} \\
\hline & $\begin{array}{l}\text { Interviews in } \\
\text { Luxor/Aswan }\end{array}$ & 91.61 & & \\
\hline & $\begin{array}{c}\text { Questionnaire in Sharm El } \\
\text { Sheikh and Cairo }\end{array}$ & 50.91 & & \\
\hline & $\begin{array}{c}\text { Interviews in Sharm El } \\
\text { Sheikh and Cairo }\end{array}$ & 92.32 & & \\
\hline
\end{tabular}

- $\mathrm{P}$-Value $<0.05=$ Significant

As shown in table (1), it can be seen that the Kruskal-Wallis $H$ test revealed seven significant among the tourism occupations; 
- First the test revealed statistically a significant difference among four analysis tools 'Questionnaire in Luxor/Aswan, Interviews in Luxor/Aswan, Questionnaire in Sharm El Sheikh /Cairo and Interviews in Sharm El Sheikh/ Cairo in terms of Dietary and Nutritious Food Specialist. Achieved the highest mean rank score $(\mathrm{M}=38.82)$.

- Second, the test revealed statistically a significant difference among four analysis tools Questionnaire in Luxor/Aswan, Interviews in Luxor/Aswan, Questionnaire in Sharm El Sheikh /Cairo and Interviews in Sharm El Sheikh / Cairo in terms of MICE Organizer. Achieved the second high mean rank score $(\mathrm{M}=36.829)$.

- Third, the test revealed statistically a significant difference among four analysis tools Questionnaire in Luxor/Aswan, Interviews in Luxor/Aswan, Questionnaire in Sharm El Sheikh /Cairo and Interviews in Sharm El Sheikh/ Cairo in terms of Animator (Animation Team Member). Achieved the third mean rank score $(\mathrm{M}=33.503)$.

- Fourth, the test revealed statistically a significant difference among four analysis tools Questionnaire in Luxor/Aswan, Interviews in Luxor/Aswan, Questionnaire in Sharm El Sheikh /Cairo and Interviews in Sharm El Sheikh/ Cairo in terms of Green Hotels Specialist. Achieved the fourth mean rank score $(\mathrm{M}=33.503)$.

- Fifth, the test revealed statistically a significant difference among four analysis tools Questionnaire in Luxor/Aswan, Interviews in Luxor/Aswan, Questionnaire in Sharm El Sheikh /Cairo and Interviews in Sharm El Sheikh/ Cairo in terms of Medical Tourism Specialist. Achieved the fifth mean rank score $(\mathrm{M}=19.928)$.

- Sixth, the test revealed statistically a significant difference among four analysis tools Questionnaire in Luxor/Aswan, Interviews in Luxor/Aswan, Questionnaire in Sharm El Sheikh /Cairo and Interviews in Sharm El Sheikh/ Cairo in terms of Eco and Safari Guide. Achieved the sixth mean rank score $(\mathrm{M}=12.898)$.

- Finally, the test revealed statistically a significant difference among four analysis tools Questionnaire in Luxor/Aswan, Interviews in Luxor/Aswan, Questionnaire in Sharm El Sheikh /Cairo and Interviews in Sharm El Sheikh/ Cairo in terms of Religious Tourism Specialist/Guide. Achieved the last mean rank score $(\mathrm{M}=9.424)$. 
1. The Mann-Whitney U test was used in this study to compare between The Tourism Occupations According to its Importance and Needs to the Egyptian Tourism Market.

Table 5 The Tourism Occupations According to its Importance and Needs to the Egyptian Tourism Market

\begin{tabular}{|c|c|c|c|}
\hline Occupations & Rank & $\begin{array}{c}\text { Std. } \\
\text { Deviation }\end{array}$ & $\begin{array}{c}\text { Weighted } \\
\text { average \% }\end{array}$ \\
\hline \begin{tabular}{r|r|r|} 
Dietary and Nutritious Food \\
Specialist
\end{tabular} & 1 & 93.1 & $22 \%$ \\
\hline MICE Organizer & 2 & 72.2 & $18 \%$ \\
\hline Medical Tourism Specialist & 3 & 69.3 & $16 \%$ \\
\hline $\begin{array}{c}\text { Animator (Animation Team } \\
\text { Member) }\end{array}$ & 4 & 64.2 & $15 \%$ \\
\hline $\begin{array}{c}\text { Green Hotels Specialist } \\
\text { Religious Tourism }\end{array}$ & 5 & 54.1 & $13 \%$ \\
\hline Specialist/Guide & 6 & 38.6 & $9 \%$ \\
\hline Eco and Safari Guide & 7 & 29.2 & $7 \%$ \\
\hline Total & & - & $100 \%$ \\
\hline
\end{tabular}

It can be concluded from the data tabulated in Table 2 that Dietary and Nutritious Food Specialist was Considered as one of the most important major occupation by an average of $93.1 \%$, secondly, MICE Organizer by an average of $72.2 \%$, thirdly Medical Tourism Specialist was an average of $69.3 \%$, fourthly, Animator (Animation Team Member) was an average of $64.2 \%$ and fifthly, Green Hotels Specialist by an average of $54.1 \%$. Sixthly, Religious Tourism Specialist/Guide by an average of 38.6 and finally, Eco and Safari Guide by an average of $29.2 \%$. As shown in figure 1 . 


\title{
Figure 1 The Tourism Occupations' Ranks according to its importance and needs to the Egyptian Tourism Market.
}

\author{
Weighted average \% \\ The Tourism Occupations Ranks According to its \\ Importance and Needs to the Egyptian Tourism \\ Market
}

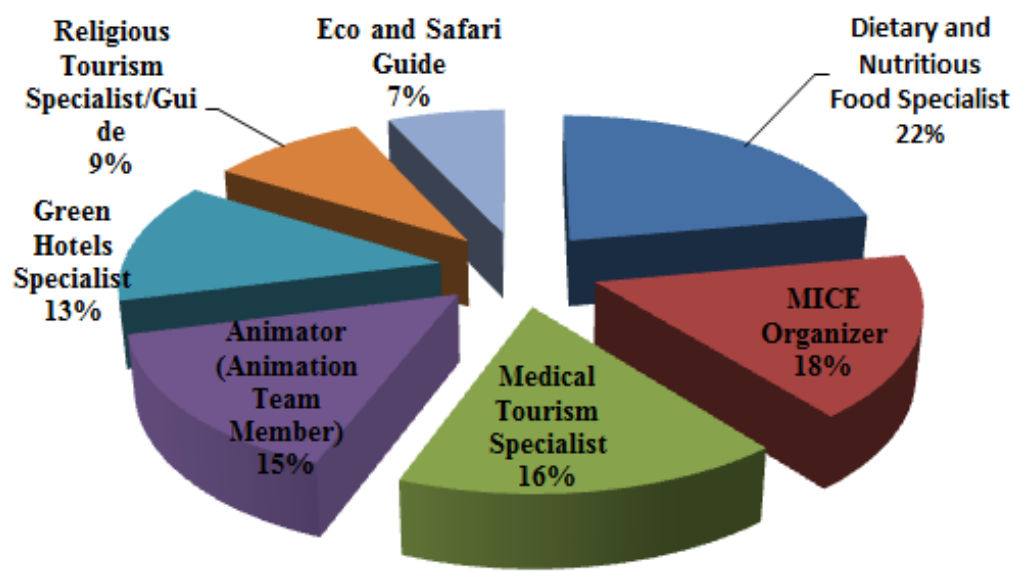

\section{SECOND: SIGNIFICANCE BEHIND THESE NEW OCCUPATIONS}

The interviewees support these findings by indicating the following:

1. Dietary and Nutritious Food Specialist Is one of the most important jobs in the current period due to the increasing awareness of guests about nutritional value of food, the notable requirements of the guests with special dietary needs and presence of taste tourism which takes a large part of the hotel propaganda at the moment. It is necessary to have a food expert to adopt the idea properly and controls the dietary and nutritional aspect in the food recipe and menu.

2. The MICE Organizer occupation: The function of Meetings, Incentives, Conventions and Event management should belong to tourism sector as the most appropriate specialized industry for MICE environment. However, sometimes it is implemented by other non-tourism and unspecialized companies that mostly carry out this task. This certainly maximizes the significance and increasing need for this occupation development to be considered and involved in the training and educational Reform Programs.

3. Animator (Animation Team Member) it is highly significant in hotels and resorts as it plays an important role in increasing the proportion of their occupancy. The majority of 
hotel establishments, especially resorts, often refer to nonEgyptians to perform such animating tasks. If there are organized training courses for Egyptians to join this career, tremendous job opportunities will be available for young people that surely by time will replace foreigners.

4. Green Hotels Specialist is very important occupation for hotel establishments as it becomes a worldwide trend to preserve the environment at any workplace. This is plus the growing interest of many hotels towards awarding different quality systems certifications like ISO 12000.

5. Medical Tourism Specialist Medical Tourism is an arising type of tourism in the world and especially in Egypt during the last decade. This is due to the current drop in inbound tourism targeting the entertainment and cultural tourism, especially after the unpleasant events and tourism crises.

6. Eco and Safari Guide Egypt is famous for unique geological features and ecological specifications that need certified ecoguides who are qualified, competent and possess scientific information. Unfortunately, eco-guidance is done by some Bedouin who acquired their knowledge spontaneously from their childhood with no education or training with certification. This certainly increases the importance of developing skills development program for certifying and/or educating eco-guides.

7. Religious Tourism Specialist/Guide This occupation has recently regarded as one of the urgently needed occupation. This is due to the fact that Vatican Pop, during his last visit to Egypt in 2017, has declared that the holly family road is a place for the Christian Hajj. Accordingly, there is a need for certifying guides specialized in such religious stories and history, to be able to offer the correct guidance to religious tourists coming from different countries for Hajj in Egypt.

\section{Third: Less Priority NeW OCCUPATIONS}

According to the reply of respondents regarding the less priority occupations, the following findings have been demonstrated:

1. Balloon Captain in Luxor: There is a need for the Balloon Pilot occupation due to its relation to tourists' safety. It is assumed that most of the Balloon Pilots do not have enough experience. Hence, the Balloon tours may face technical problems that could be a threat not only to the tourist activities in Luxor but also to the tourist activities in Egypt. 
2. Nile Cruise Captain in Luxor and Aswan: It is somehow an important occupation owing to its relation to tourists' safety. Moreover, this occupation includes many jobs, since every Cruise needs a Captain and an assistant Captain and about nine other sailors. All of them gain the sealing experience without any training or educating courses. Thereby, there are many new sealing equipment in the Nile Cruises, specially the new cruises, are not be used because captains are ignorant of the know-how and consequently, could not deal with it. Moreover, there are about 200 Nile Cruises sailing between Luxor and Aswan which mean this industry need about 2200 jobs relating to this occupation.

3. First Aid Professional: It's considered one of the needed new occupations since it is related to the safety and lifesaving of the guest. Furthermore this job is indispensable to occur at any tourist establishment whether hotel, restaurant, Nile Cruise, tourist vehicle and during Safari and diving activities.

4. Hotel Equipment Specialist: It's more or less significant since hotel establishments require a specialist that understand and estimate hotel needs for the appropriate equipment as well as schedule with the maintenance and engineering department a program for regular checking and maintenance

5. HACCP Specialist: This job is needed since HACCP is one of the quality assurance program mostly utilized in many hotels and resorts. However, it's not urgently important since some hotels refer to outsourcing companies specialized in HACCP auditing.

\section{FOURTH: RECOMMENDATIONS}

1. Suggestions to employ the top priority Occupations in curricula development

- Take real decisions from the government to employ these new occupations officially in the training and skills development programs as beneficiary tools for curricula development.

- Establish a committee in one of the higher education authorized organizations to be responsible for identifying and utilizing the new occupations in business sectors including tourism and hospitality sector

- Hold a series of meetings with the participation of the related organizations to take decisions concerning these occupations 
development in terms of setting up its profile, job descriptions and intended learning outcomes (ILOs) for each occupation

- Set up educating and training courses for these occupations sponsored by the tourism institutions related to higher education and the tourism authorized organizations.

- Hold a group of workshops and awareness campaigns in tourism colleges and institutes to shed the light on the importance of these occupations.

2. Proposed implementation mechanism for linking new occupations with curricula development programs in tourism and hotels higher education

According to interview analysis and the feedback stated by respondents the following diagram has been drawn up and proposed as an implementation mechanism for linking new occupations with curricula development programs in tourism and hotels higher education. The diagram interprets three phases: Phase I "Approving the new occupations", Phase II "Preparing the profile of the new occupation" and Phase II "Developing tourism and hotels high education curricula". Figure 2 manifests the diagram concept.

\section{Figure 2 Implementation mechanisms for linking new occupations with curricula development programs}

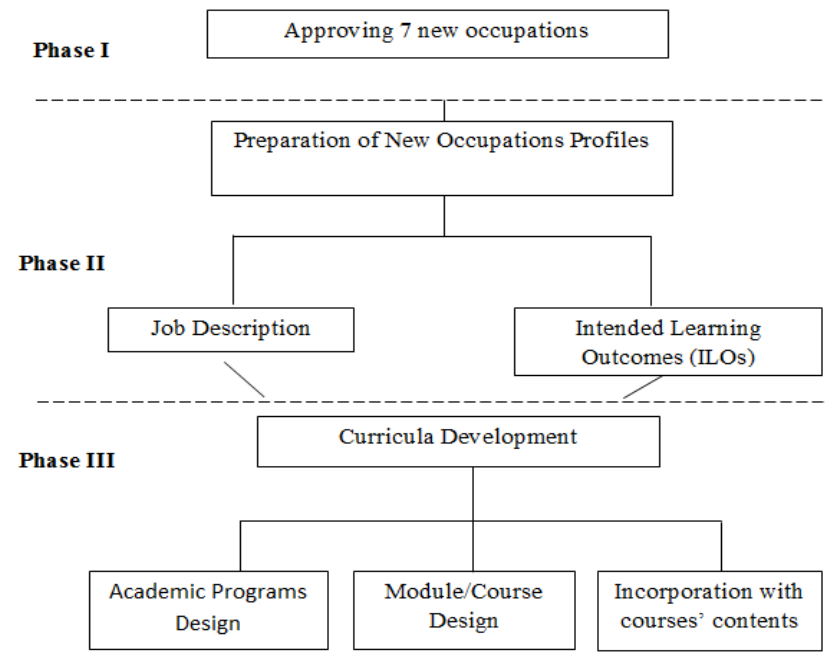

It has been recommended to hold a committee that consists of members representing the tourism market experts as well as academic professors in tourism and hotel management education. This committee is responsible for implementing the mechanism for linking 
new occupations with curricula development programs throughout three phases:

Phase I: holding a series of workshops for reviewing the proposed new occupations and verifying their significance in the Egyptian tourism market and the necessity of linking them to tourism and hotels' higher education programs

Phase II: Prepare the profile of each occupation through a group of meetings and workshops in terms of preparing and developing the job descriptions and the ILOs of each occupation as a basic tool utilized for curricula development

Phase III: Classify curricula development into three methods depending on the environment of each occupation and context as follows:

- First Method: through designing a specific academic program depending on the contents of the occupation such as undergraduate program, post graduate diploma, master of doctorate program. For example, design a master program for MICE organization involving all levels of this occupation.

- Second Method: through designing a module or academic course through preparing course specifications depending on the identified job description and ILOs

- Third Method: Incorporate the new occupation job description and ILOs to some of the currently existing courses or modules so as to enrich them with full information about the job and qualify students with job requirements of the new occupation

- Finally, it is also recommended that the final work of the committee is reported in a draft and presented to one of the authorized entity which is specialized in tourism and hotel management higher education curricula development for actual implementation

\section{REFERENCES}

Abu El-Azm, N. and Abd Eljalil, S., (2017). Examining the Critical Success Factors as an Approach of Events Management in Egypt and United Arab Emirates, MJTHR, 2, (2), 25- 50.

Akhalaia,N., and Vasadze,M., (2016). New trends in Hospitality Industry and Georgia, Advances in Management and Applied Economics, 6, (6), 83-88. 
Bamford,K.L.,(2012).Undergraduate Student Perceptions of a Career in The Tourism and Hospitality Industry in New Zealand, Master Thesis, University of Otago, Dunedin, New Zealand Available at:

https://ourarchive.otago.ac.nz/bitstream/handle/10523/2448/bamfordki rsten lmtour.pdf?sequence=1 Accessed on 1/8/2018.

Batinic,I., (2013).Current Trends in Hospitality Industry, Journal of Process Management New Technologies, International, 1, (4),9195.

Becic,E.,and Crnjar,K.,(2009).Trends on The Tourism Labor Market, Tourism and Hospitality Management, 15, (2),205- 216.

Biswakarma, G.,(2016). Relationship of Tourism academic, Employability Abilities and Skills and Human Resource Development in Nepalese Tourism Industry, 3, (2),20- 35.

Conradie,R.,(2012). Student Evaluation of Career readiness after Completing The hospitality Management Curriculum at The International Hotel School, Master Thesis, University of South Africa, available at: https://core.ac.uk/download/pdf/43170782.pdf Accessed on 2/8/2018.

Cormany, D. and Baloglu, S., (2010). Medical travel facilitator websites: An exploratory study of web page contents and services offered to the prospective medical tourist. Tourism Management, 32, 709-716.

Csirmaz, E., and Peto, K., (2015).International Trends in Recreational and Wellness Tourism, Procedia Economics and Finance, 32,755-762.

Dredge, D., (2016). Of Things to Come:Tourism and Hospitality Education in apost- Industrial Age, The Business of Tourism,(17),19-23.

Erisher, W., (2013). Qualifications must address the needs of Commerce in Zimbabwe: A case of the Hospitality Discipline, Journal of Research \& Method in Education,3,(5), 1-5.

Galbraith, A., Bankhead, (2012). Sector Skills Assessment for the Hospitality Tourism and Sport Sector, UK, Commission for Employment and Skills, briefing paper, October. Available at: https://assets.publishing.service.gov.uk/government/uploads/syst em/uploads/ attachment_data/file/306403/briefing-paper-ssa12hospitality-sport- tourism.pdf Accessed on 2/8/2018 .

International Labor organization (2010). Development and hallenges in Hospitality and tourism sector, Issues paper for discussion at the Global Dialogue Forum for the Hotels, Catering, Tourism Sector, 23-24 November. Available at: 
http://www.ilo.org/wcmsp5/groups/public/@ed_norm/@relconf/docu ments/ meetingdocument/wcms_166938.pdf Accessed on 28/7/2018.

Jakovlev,Z.,Koteski,C.,Bradarova,S.,Zezova,A.,Dzambazoski,K.,and Koteski,G.,(2014). Animator's Roles in Enriching the Content of Tourist Stay, Journal of Tourism and Hospitality Management, 2, (3), 133-139.

Ju, H. C., and Lo, R.C., (2014). Perceptions, Attitudes, and Needs of Undergraduate Student towards Career in the Hospitality Industry- An Example from the Undergraduate Students in Taiwan Shoufu University, 9, (2), 20- 32.

Km,K., and Sharma, P.,(2011). Gap Analysis of Skills Provided in Hotel Management Education with Respect to Skills Required in the Hospitality Industry: The Indian Scenario, International Journal of Hospitality and Tourism System, 4, (1), 31- 51.

Liburd, J. J., Mihalic, T., and Guia, J., (2018). Values in tourism higher education: The European master in tourism management, Journal of Hospitality, Leisure, Sport and Tourism Education, 22, 100- 104.

Luka, I., and Donina, A., (2012). Challenges of Tourism Education: Conformity of Tourism Curriculum to business need, Academica Turistica, 5, (1), 85- 101.

Luka, I., and Donina, A., (2014). The Compliance of Tourism Education with Industry Needs in Latvia, European Journal of Tourism, Hospitality and Recreation, Special Issue, 303- 330.

Melia, D., (2011).Trends in Food and Beverage Sector of the Hospitality Industry, EuroCHRIE Conference, Dubrovnik, Croatia, October, available at: https://arrow.dit.ie/cgi/viewcontent.cgi?article=1049\&context=tf schmtcon Accessed on 16/9/2018 .

Millar, M., and Baloglu, S., (2008). Hotel Guests' Preferences for Green Hotel Attributes, Proceedings of the European Council for Hotel, Restaurant, and Institutional Education Conference, Dubai, United Arab Emirates, Available at: https://repository.usfca.edu/cgi/viewcontent.cgi?article=1007\&c ontext=hosp Accessed on 14/9/2018 .

Ottenbacher, M.C. and Harrington, R.J., (2009). The Product Innovation Process of Quick Service Restaurant Chains. International Journal of Contemporary Hospitality Management, 21, (5), 523- 541. 
Patino, M. G., Medina, F. X., and Arilla, J.M.P., (2016).New Trends in Tourism? From Globalization to Postmodernism, International Journal of Scientific Management Tourism, 2, (3), 417-433.

Rao, R. S., and Pradesh,V.D., (2014). Emerging Trends in hospitality and Tourism, International Journal of Research Granthaalayah, 1, (1), $1-8$.

Sadik, A., (2017).Emerging Trends and Influences in Ghanaian Hospitality Industry Education and Employability, PHD Thesis, Sheffield Hallam University. Available at: http://shura.shu.ac.uk/16810/1/Sadik\%20_2017_Emerging_Trends_Vo R.pdf Accessed on 2/8/2018.

Skanavis, C., and Giannoulis, C., (2010). Improving Quality of ecotourism Through Advancing Education and training of Greek Eco-tour Guides: The role of Training in Environmental Interpretation, An International Multidisciplinary Journal of Tourism, 5, (2), 49- 68.

Stanciulescu, G.C.J., and Bulin, D., (2012). Shaping Tourism Higher Education Curriculum - Strategy to Develop Skills For Tomorrow's Jobs, Procedia Economics and Finance, 3, 12021207.

Steinsdóttir, T., (2014). Responsibilities of Tour Guides in Religious Tourism, thesis submitted in partial fulfillment of a Bachelor of Arts degree in Tourism, Department of Tourism, Holar University College.

Veal, A., (2006). Research methods for Leisure and Tourism, 3rd ed,Great Britain: Prentice Hall..

Wang, J., Ayres, H., and Huyton, J., (2009). Job Ready Graduates: A Tourism Industry Perspective, Journal of Hospitality and Tourism Management, 16, (1), 62- 72.

Willimas, M., Luanaigh, A.N., and Garret, R., (2012). Sector Skills Insights: Tourism, UK Commission for Employment and Skills, Evidence Report 55, August, Available at: http://dera.ioe.ac.uk/15965/1/evidence-report-55-tourism.pdf Accessed on $24 / 7 / 2018$.

Zaitseva, N. A., Goncharova, I. V., and Androseenko, M. E., (2016).

Necessity of Changes in the System of Hospitality Industry and Tourism Training in Terms of Import Substitution, International Journal of Economics and Financial Issues, Vol. 6, No.1.

Zhao, W. J., and Jing, W., (2009). Issues, Challenges, and Trends, that Facing Hospitality Industry, Management Science and Engineering, 3, (4), 53- 58. 